\title{
BMJ Global Health Policing is a threat to public health and human rights
}

\author{
Thilagawathi Abi Deivanayagam (D) , Sarah Lasoye (1) , ${ }^{2}$ James Smith (D) , ${ }^{3}$ \\ Sujitha Selvarajah (1) ${ }^{2}$
}

To cite: Deivanayagam TA, Lasoye S, Smith J, et al. Policing is a threat to public health and human rights. BMJ Global Health 2021;6:e004582. doi:10.1136/ bmjgh-2020-004582

Received 28 November 2020 Accepted 3 December 2020

Check for updates

C C Author(s) (or their employer(s)) 2021. Re-use permitted under CC BY-NC. No commercial re-use. See rights and permissions. Published by BMJ.

${ }^{1}$ Department of Public Health and Policy, Institute of Population Health Sciences, University of Liverpool, Liverpool, UK

${ }^{2}$ Institute for Global Health, University College London, London, UK

${ }^{3}$ Department of Global Health and Development, London School of Hygiene and Tropical Medicine, London, UK

Correspondence to

Sarah Lasoye;

s.lasoye@ucl.ac.uk

\section{PROBLEMATISING THE INSTITUTION OF POLICING}

The impact of policing on individual and collective well-being and human rights has gained renewed attention. In 2020, global protests against police violence, racism and white supremacy were met with further violence by state security actors. In Nigeria, at least 56 people were killed during protests in opposition to the Nigerian police force's 'Special AntiRobbery Squad' in October 2020 alone. ${ }^{1}$

Peripheral calls to defund and abolish the police have gained extraordinary mainstream support. Such a shift has coincided with public scrutiny of state responses to the ongoing COVID-19 pandemic, examination of public investment in health and social services, and calls to eliminate militarised and biosecuritised public health responses. ${ }^{2}$

We must understand the extent to which policing has been framed as essential to the function of safe societies. Substantial sociological and philosophical inquiry has long recognised contemporary policing as a product of disciplinary and regulatory power, and as a tool to preserve 'inequality and maintaining the status quo' ( $\mathrm{p} 15) .{ }^{3}$

Adopting a term first coined by Ture and Hamilton, the UK government's inquiry into the handling of Stephen Lawrence's murder identified widespread 'institutional racism' in the UK police service. ${ }^{4}$ Despite its applicability to other contexts and institutions, identifying policing as racist differs from referring to other institutions as such: racism and discrimination are not byproducts of policing, but central to its function. Policing has not become racist or discriminatory, but has always existed as a tool to maintain racist and other power hierarchies. In the USA, modern policing evolved from decentralised, privately funded slave patrols. In Australia and Canada, policing remains a weapon of colonial and neocolonial control, evidenced by legislation mandating the forced removal of indigenous children from their families.
Summary box

Policing is a public health concern because it is a tool of racist and discriminatory power structures, actively harming the physical, mental, social and emotional health and well-being of populations, particularly Black and people of colour, and other minoritised populations.

- Policing is a matter of public health because criminalisation and punitive responses to social problems reproduce the social and economic conditions that result in criminalised behaviours, undermining healthy communities.

- A fundamental tenet of abolitionist public health is developing and implementing interventions that tackle the interpersonal, social, economic and political determinants of health at the root of societal problems, thus making policing obsolete.

- Defunding the police and reallocating public funds to primary and secondary preventative policies aligned with the social determination of health are essential steps towards abolition.

- We call for the support and creation of alternative systems that centre collective care and well-being and a non-violent public health rooted in transformative justice.

Aside from the institution, acts of policing are pervasive across other contexts. In healthcare, policing dominates the response to people experiencing mental health crises. Disruption in educational settings is dealt with punitively, with Black students more likely to be permanently excluded from school. Efforts have been taken to impose state censorship of critical race theory from public discourse. Not only is policing as an institution racist, but policing across a multitude of contexts upholds racism and other oppressive hierarchies.

\section{POLICING AND THE RACIST CONSTRUCTION OF CRIMINALITY}

Not all acts of harm are criminalised, and not all criminalised acts are harmful. Policing reinforces white supremacy and capital accumulation in several ways, particularly through 
the disproportionate targeting of minoritised groups. ${ }^{5}$ As anthropologist Didier Fassin observes, 'the general evolution of policing worldwide has been toward the harsh version of law enforcement [...] systematically imposed as a form of government of the most precarious and marginalized groups' ( $\mathrm{p} 216) .{ }^{6}$ This pursuit of social control that led to the proliferation of the police is embodied in the practices of violence, control and incarceration that define modern policing, and its substantial health and socioeconomic consequences.

In the USA, Black, Indigenous and people of colour (BIPOC) are disproportionately subject to state violence, surveillance and its adverse health outcomes. ${ }^{7}$ In the UK, data reveals similar disparities in police targeting and criminalisation faced by Black and other minoritised people; in 2018, a national analysis revealed Black people were almost nine times more likely to be stopped by the police than their white counterparts, with only 1 in 10 of those stops leading to an arrest. ${ }^{8}$ In $2019,16 \%$ of all police uses of force and $20 \%$ of electro-shock weapon usage in the UK were against Black people, despite constituting just over $3 \%$ of the population. ${ }^{9}$ In Australia, Aboriginal and Torres Strait Islanders comprise $28 \%$ of the total adult prison population, but just $2 \%$ of the adult population. ${ }^{10}$ Police officers in Brazil's Rio de Janeiro state have killed over 8000 people in the past decade, with the number of unlawful killings rising, the majority of whom are young Black men. ${ }^{11}$ In India, 1731 people were killed in police custody in 2019, the majority of whom were Muslims and Hindus from Scheduled Castes and Tribes. ${ }^{12}$

We must interrogate who is being policed, what behaviours and acts are positioned as criminal, and why punitive action is the state's primary response to such incidents. Racism is starkly expressed in the positioning of minoritised people closer to criminality. Abolitionist scholar Ruth Wilson Gilmore defines racism as the 'statesanctioned or extralegal production and exploitation of group-differentiated vulnerability to premature death' (p 28). ${ }^{13}$ Policing, and the broader prison industrial complex (PIC) of which it forms a part, is designed to uphold this social stratification. Well-trained police officers sustain this stratification, not necessarily by prejudice or incidental misunderstanding, but by system design: largely by making arrests for low-level offences, for which the burden continues to fall primarily on BIPOC. ${ }^{3}$ Thus, policing is a racist institution that traffics in criminalisation and confinement. Its function is generative of a number of harms, including the criminalisation of people with mental health disorders, the unhoused and those living in poverty, which only serves to exacerbate such conditions and denies people the right to a dignified and healthy life. We must think critically about the implications of supporting an institution whose sole response to the consequences of unmet need is criminalisation and the perpetuation of inequality.

Punitive and carceral responses to crime neither meet the needs of underserved communities, nor attempt to solve the upstream social, economic and political issues that give rise to crime. Even if certain police departments attempted to address these upstream issues, the wider PIC would continue to perpetrate harm and reproduce the social conditions that in turn beget criminalised behaviours. Reoffending rates alone illustrate that the carceral state, increasingly militarised policing and the conveyor belt of privately operated mega-prisons built plainly for profit, neither rehabilitate so-called offenders, nor offer transformative justice to communities or end crime. Rather, these systems produce and reproduce violence.

\section{POLICING CAUSES POOR HEALTH FOR EVERYONE THROUGH COMMUNITY DISEMPOWERMENT}

State violence enacted by the police and systems of incarceration directly harms health through harassment, sexual violence, and as a cause of poor physical and mental health. Indirectly, policing reproduces the social and economic conditions that become the root causes of crime, which are used as justifications for increased policing. ${ }^{14}$ This cycle is harmful to health.

There are many documented links between policing and health-related outcomes, including but not limited to: fatal injuries that increase population-specific mortality rates; adverse physiological responses that increase morbidity; psychological stress; arrests, incarcerations, and legal, medical and funeral bills that cause socioeconomic deprivation; poor school performance; incomplete high-school education and not entering higher education; and the intersecting oppressive structures that result in systematic disempowerment and the destruction of civil liberties. ${ }^{715-17}$

Within healthcare and beyond, we must expose structures operating to criminalise, punish and disrupt communities, foreclose opportunities, enact violence and invisibilise people rather than address their needs. As such, the case for abolition elucidates itself.

\section{TOWARDS AN ABOLITIONIST PUBLIC HEALTH}

For the public health community, abolition is both a tool and a long-term goal. We define abolitionist public health as work directed towards at the dissolution of the PIC, recognition of its discriminatory roots, and the implementation of interventions that tackle the social, economic and political determinants of health at the root of societal problems, thus making policing obsolete. This includes prioritising access to housing, better education and employment opportunities, and increasing funding for mental health and substance misuse services, to name a few. ${ }^{18}$ Abolition involves restoring community trust by divesting from institutions that discriminate against and harm our communities. ${ }^{19}$ The American Public Health Association has advocated for abolition as the reallocation of resources using the social determinants of health approach to reduce community trauma and interpersonal harm, improving community health and safety. ${ }^{20}$ 
Positioning the institution of policing as a public health issue is the crucial first step. We must recognise that the privileged among us are recipients of a safety that is predicated on violence and harm against minoritised communities.

While we work towards abolition, we call for improved data on mortality and morbidity caused by policing. This includes deaths in custody and prisons, but also the indirect impact on wider communities. We urge colleagues to study the public health consequences of police interactions with the public, especially minoritised people who are already disproportionately subject to police force and suffer more adverse health outcomes. ${ }^{7}$ As evidence grows, we call for the abolition of current systems that actively harm individuals and communities, and the creation of alternative systems that centre collective care and well-being.

We urge health practitioners to join the lineage of abolitionist thinkers who have developed robust principles of transformative justice. We advocate for a public health that promotes equity and rights, rooted in collective public interest, and that is proactive, non-violent and abolitionist. ${ }^{5}$ Globally, we routinely witness the progressive and systematic defunding of institutions integral to a healthy society, education, social care and public health. It is imperative that we now push for the defunding and abolition of an institution that fragments society and maintains hierarchical power and inequity, while simultaneously investing in systems that foster collective care, compassion and freedom.

Twitter Thilagawathi Abi Deivanayagam @abideivo, Sarah Lasoye @sarahfovea, James Smith @jimblejay and Sujitha Selvarajah @_Sujitha_S

Acknowledgements We would like to thank Dr Rhea Boyd for her ongoing work in this area in the USA and for her contributions. We would also like to thank Dr Delan Devakumar for his input during initial discussions.

Contributors TAD initiated a draft of key conceptual points to which JS and SL inputted and which was used to prepare an early draft. All authors made text input to iterative drafts and provided reference materials using shared online document editing software. TAD coordinated the inputs and edited the final manuscript.

Funding The authors have not declared a specific grant for this research from any funding agency in the public, commercial or not-for-profit sectors.

Competing interests TAD is an academic contributor and member of the advocacy stream at Race and Health, a network of academics, healthcare professionals, activists and other individuals from within and outside the medical and public health fields who want to highlight and tackle the impact of racism, xenophobia and discrimination on health. SS is the coordinator and a co-founder of Race and Health. SL is also a co-founder of Race and Health. The group came together through the Race and Health platform.

Patient consent for publication Not required.

Provenance and peer review Not commissioned; internally peer reviewed.

Data availability statement There are no data in this work.

Open access This is an open access article distributed in accordance with the Creative Commons Attribution Non Commercial (CC BY-NC 4.0) license, which permits others to distribute, remix, adapt, build upon this work non-commercially, and license their derivative works on different terms, provided the original work is properly cited, appropriate credit is given, any changes made indicated, and the use is non-commercial. See: http://creativecommons.org/licenses/by-nc/4.0/.

\section{ORCID iDs}

Thilagawathi Abi Deivanayagam http://orcid.org/0000-0002-1130-2333

Sarah Lasoye http://orcid.org/0000-0002-2408-3555

James Smith http://orcid.org/0000-0001-8768-1918

Sujitha Selvarajah http://orcid.org/0000-0002-5866-2803

\section{REFERENCES}

1 Amnesty International. Nigeria: Killing of \#EndSARS protesters by the military must be investigated, 2020. Available: https://www. amnesty.org/en/latest/news/2020/10/killing-of-endsars-protestersby-the-military-must-be-investigated/ [Accessed 27 Nov 2020].

2 Loewenson R, Accoe K, Bajpai N, et al. Reclaiming comprehensive public health. BMJ Glob Health 2020;5:e003886.

3 Vitale AS. The end of policing. New York, USA: Verso, 2017.

4 Carmichael S, Hamilton CV. Black power: the politics of liberation in America. New York, USA: Vintage Books, 1967.

5 Iwai Y, Khan ZH, DasGupta S. Abolition medicine. Lancet 2020;396:158-9.

6 Fassin D. Enforcing order: an ethnography of urban policing. Cambridge, UK: Polity, 2013.

7 Bor J, Venkataramani AS, Williams DR, et al. Police killings and their spillover effects on the mental health of black Americans: a population-based, quasi-experimental study. Lancet 2018;392:302-10.

8 et alShiner M, Carre Z, Delsol R. The colour of injustice: 'race', drugs and law enforcement in England and Wales, 2020. Available: https://www.release.org.uk/sites/default/files/pdf/publications/The\% 20Colour\%20of\%20Injustice.pdf [Accessed 27 Nov 2020].

9 UK Home Office. Police use of force statistics, England and Wales April 2018 to March 2019, 2019. Available: https://www.gov.uk/ government/statistics/police-use-of-force-statistics-england-andwales-april-2018-to-march-2019 [Accessed 27 Nov 2020].

10 Axleby $\mathrm{C}$, Waight $\mathrm{N}$. We need to go beyond empty gestures if we're going to end Aboriginal deaths in custody, 2020. Available: http:// www.theguardian.com/commentisfree/2020/jun/29/we-need-to-gobeyond-empty-gestures-if-were-going-to-end-aboriginal-deaths-incustody [Accessed 27 Nov 2020].

11 Human Rights Watch. Brazil: Extrajudicial executions Undercut Rio security, 2016. Available: https://www.hrw.org/news/2016/07/07/ brazil-extrajudicial-executions-undercut-rio-security [Accessed 27 Nov 2020].

12 Gettleman J, Yasir S. Hundreds of police Killings in India, but no mass protests, 2020. Available: https://www.nytimes.com/2020/08/ 20/world/asia/india-police-brutality.html [Accessed 27 Nov 2020].

13 Gilmore RW. Golden Gulag: prisons, surplus, crisis, and opposition in globalizing California. Berkeley, USA: University of California Press, 2007.

14 Carbado DW. Blue-on-Black violence: a provisional model of some of the causes. Georgetown Law Journal 1479 (2016), UCLA School of Law, Public Law Research Paper No. 16-31 2016.

15 Alang S, McAlpine D, McCreedy E, et al. Police brutality and black health: setting the agenda for public health scholars. Am J Public Health 2017;107:662-5.

16 Ang D. The effects of police violence on inner-city Students*. Q J Econ 2020;136:115-68.

17 Sewell AA, Jefferson KA, Lee H. Living under surveillance: gender, psychological distress, and stop-question-and-frisk policing in New York City. Soc Sci Med 2016;159:1-13.

18 AMA. Ama urges lawmakers to act on policing reform to protect public health, 2020. Available: https://www.ama-assn.org/presscenter/press-releases/ama-urges-lawmakers-act-policing-reformprotect-public-health [Accessed 27 Nov 2020].

19 World Health Organization. A conceptual framework for action on the social determinants of health. Geneva, Switzerland, 2010. Available: https://www.who.int/sdhconference/resources/Conceptualframew orkforactiononSDH_eng.pdf [Accessed 27 Nov 2020].

20 American Public Health Association. Addressing law enforcement violence as a public health issue. The 2018 statement, 2018. Available: https://www.endingpoliceviolence.com/the-2018statement [Accessed 27 Nov 2020]. 